\title{
Morphology and taxonomy of Aulacoseira muzzanensis (Bacillariophyta)
}

\author{
S. I. Genkal ${ }^{1}$, I. S. Trifonova ${ }^{2}$ \\ ${ }^{1}$ Papanin Institute for Biology of Inland Waters of Russian Academy of Sciences, Borok, Russia \\ ${ }^{2}$ Institute of Limnology Russian Academy of Sciences, St. Petrsburg, Russia \\ Corresponding author: S. I. Genkal, Genkal@ibiw.ru
}

\begin{abstract}
Morphological investigation of wild populations of Aulacoseira granulata shows significant variability of its quantitative morphological characteristics: valve diameter and height; number of rows of areolae and number of areolae in $10 \mu \mathrm{m}$ on the valve mantle; and number of spines and their length on separation valves. Low values of mantle height to valve diameter ratio and large numbers of areolae in $10 \mu \mathrm{m}$, typical for A. muzzanensis, are also found in populations of $A$. granulata. The valve height/diameter ratio decreases as the valve diameter increases, and such relationships also occur in other taxa of this genus (A. baicalensis, A. islandica, and A. subarctica). No correlation is found between valve diameter and number of spines in separation valves. Our investigations confirm the correctness of referring A. muzzanensis to the synonymy of $A$. granulata, and based on original and published data, we suggest emendation of the diagnosis of $A$. granulata.

Keywords: Aulacoseira, Aulacoseira granulata, diatoms, frustule morphology, scanning electron microscopy, taxonomy.
\end{abstract}

\section{Морфология и таксономия Aulacoseira muzzanensis (Bacillariophyta)}

\author{
С. И. Генкал ${ }^{1}$, И. С. Трифонова ${ }^{2}$ \\ ${ }^{1}$ Институт биологии внутренних вод им. И. Д. Папанина РАН, Борок, Россия \\ ${ }^{2}$ Институт озероведения РАН, Санкт-Петербург, Россия \\ Автор для переписки: С. И. Генкал, Genkal@ibiw.ru
}

Резюме. Изучение морфологии панциря в природных популяциях Aulacoseira granulata показало значительную изменчивость количественных признаков: диаметра створки и ее высоты, числа рядов ареол и ареол в 10 мкм на загибе створки, числа и длины шипов на разделительных створках. Небольшие значения отношения высоты створки к ее диаметру и высокие числа ареол в 10 мкм, характерные для A. muzzanensis, встречаются и в популяциях A. granulata. Показано, что с увеличением диаметра створки уменьшается отношение высота створки/диаметр створки и такая зависимость наблюдается и у других представителей этого рода: $A$. baicalensis, A. islandica, A. subarctica. Не выявлено корреляции между диаметром створки и числом шипов у разделительных створок. Наши исследования подтверждают корректность сведения A. muzzanensis в синонимику к A. granulata и на основе оригинальных и литературных данных предлагается расширить диагноз A. granulata

Ключевые слова: Aulacoseira, Aulacoseira granulata, диатомовые, морфология панциря, сканирующая электронная микроскопия, таксономия.

Melosira muzzanensis F. Meist. was described in 1912 (Meister, 1912). Then, a new combination for $M$. granulata was suggested $-M$. granulata var. muzzanensis (F. Meist.) Hust. (Hustedt, 1930). This combination is the variety included in the first 
Russian systematic report of diatom algae (Zabelina et al., 1951). Later, M. granulata var. muzzanensis was changed to Aulacoseira muzzanensis (F. Meist.) Krammer (Krammer, 1991), but the systematic position of this species remains in question. Melosira granulata var. muzzanensis was mentioned in some publications in the $1960^{\text {s }}$ (Ermolaeva, 1967; Kuzmin, Elizarova, 1967), but a monograph by Skabichevsky (1960) referred this variety to the synonymy of $M$. granulata (Ehrenb.) Ralfs. In work on Centrophyceae this variety is described as a synonym of Aulacoseira granulata (Ehrenb.) Simonsen (Davydova, Moiseeva, 1992).

The independent taxonomic status of A. muzzanensis was recognized in other publications (Krammer, 1991; Krammer, Lange-Bertalot, 1991; Algae..., 2009; Potapova, English, 2011). Notably, Krammer and Lange-Bertalot (1991) believe that A. muzzanensis differs from $A$. granulata by a lower mantle height to valve diameter ratio $(\mathrm{h} / \mathrm{d})$ and a greater number of areolae in a row on the valve mantle. However, one more combination, A. granulata var. australiensis (Grunow) Moro was described based on the difference from the type variety in the valve diameter, position of areolae on the valve face and the number of spines on the separating spines (Moro, 1991).

There are other species similar to A. muzzanensis. One is A. gessneri (Hust.) Simonsen (Wetzel et al., 2014). Valves of $A$. muzzanensis have usually slightly spiral dextrorse rows of areolae on the valve mantle, which have never been observed in $A$. gessneri and clearly separate these species. A species similar to A. muzzanensis, A. brasiliensis Tremarin, Torgan et T. Ludwig (Tremarin et al., 2012), has been recently described. It differs from A. muzzanensis by the length of spines, position of areolae on the valve face and mantle, and the position and structure of rimoportulae. Even more recently, A. pseudomuzzanensis Olsyński et Żelana-Wieczorek was described by Olszyński et Żelazna-Wieczorek (2018). This species differs from A. muzzanensis by the number of areolae in $10 \mu \mathrm{m}$ on the mantle, position of areolae on the valve face, and structure of rimoportula.

The aim of this study is to investigate the morphological variability in populations of A. granulata and specify the systematic position of A. muzzanensis.

\section{Material and methods}

This study used SEM micrographs of valves of A. granulata from Cheboksar (July 1981), Ivankovo (August 1991) and Sestroretsk Razliv reservoirs (August 2016); A. islandica from the Amur River (March 1997) and Lake Khanka (March 1993); A. baicalensis from Middle Baikal (May 1984); A. subarctica from lakes Krasnoe (August 2004) and Kurilskoe (August 1967).

Diatom frustules were treated from organic matter by cold burning (Balonov, 1975) with sulphuric acid and potassium dichromate. Cleaned specimens were dried on stubs, coated with gold using an EIKO-IB-3 sputter coater, and examined using a JSM-25S scanning electron microscope operating at $15 \mathrm{kV}$. 


\section{Results and discussion}

In the population from the Cheboksar Reservoir, the range of variability of quantitative morphological characteristics, including mantle height/diameter $(\mathrm{h} / \mathrm{d}) \mathrm{ra}-$ tio, is similar in separation valves and valves in the filament (Table 1). These features correspond to the published data on A. granulata and A. muzzanensis, except for the separation valves by the number of areola rows in $10 \mu \mathrm{m}$ and areolae in $10 \mu \mathrm{m}$, and fine-structure valves in the filament of $A$. muzzanensis by the number of areola rows in $10 \mu \mathrm{m}$ and areolae in $10 \mu \mathrm{m}$ (Table 2). Unfortunately, no information is available on the number of spines on separation valves. Kiss et al. (2012) reported 2-4 long spines for $A$. granulata. In valves from the Cheboksar Reservoir population, we recorded 1 to 7 spines, including long and more short ones (Fig. 1b). There were usually more longer spines, and we found no relationship between their number and the valve diameter (Fig. 1c). In their quantitative morphological characteristics, the valves from the Ivankovo Reservoir and Sestroretsk Razliv (Table 1) also corresponded to published data (Table 2), except for maximum values of valve diameter in the population from the highly eutrophic Sestroretsk Razliv $(37.1 \mu \mathrm{m})$.
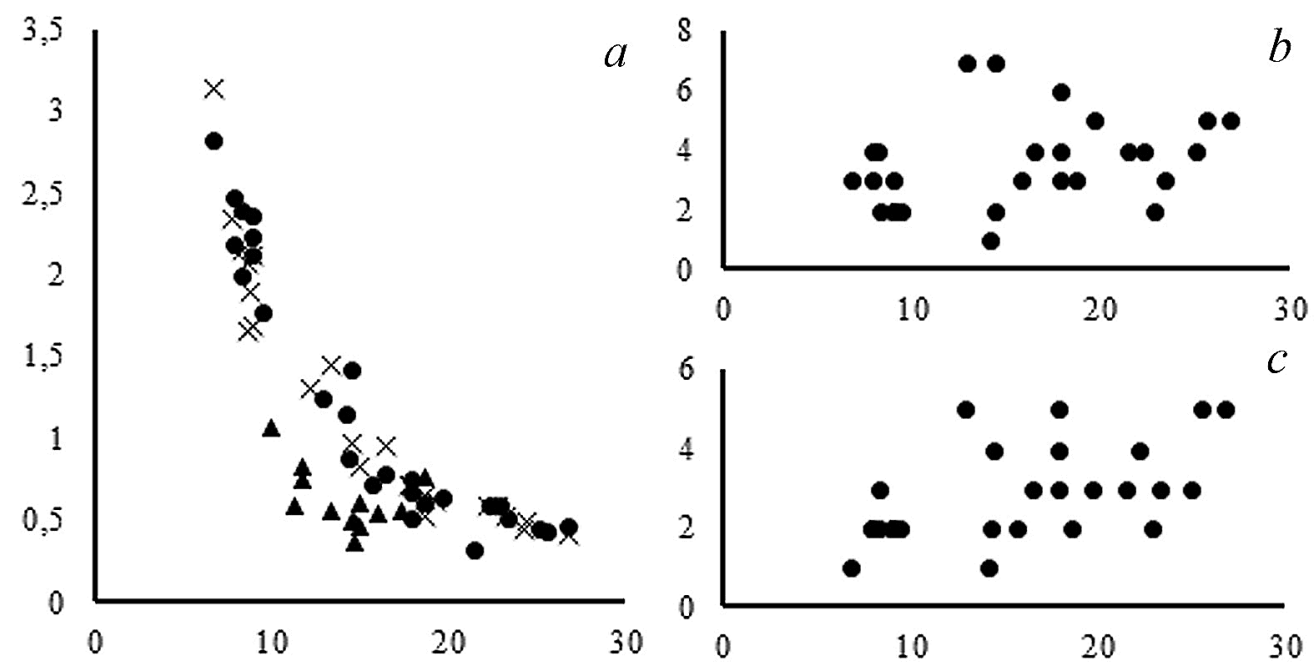

Fig. 1. (a) Aulacoseira granulata, relationship between the valve diameter (axis $\mathrm{X}, \mu \mathrm{m}$ ) and mantle height to valve diameter ratio (axis $\mathrm{Y}$ ); $\bullet$ : separation valves, $\times$ : valves in the colony, $\boldsymbol{\Delta}$ : valves from Lago di Muzzeno (Krammer, 1991). (b) A. granulata, relationship between valve diameter (axis X, $\mu \mathrm{m}$ ) and long and more short spines (axis Y). (c) A. granulata, relationship between valve diameter (axis $\mathrm{X}, \mu \mathrm{m}$ ) and long spines (axis $\mathrm{Y}$ ). 
The variability of morphological features of Aulacoseira granulata

\begin{tabular}{|c|c|c|c|c|l|}
\hline $\begin{array}{c}\text { Valve } \\
\text { diameter, } \\
\mu \mathrm{m}\end{array}$ & $\begin{array}{c}\text { Valve } \\
\text { height, } \mu \mathrm{m}\end{array}$ & $\begin{array}{c}\text { Mantle height to } \\
\text { valve diameter } \\
\text { ratio }\end{array}$ & $\begin{array}{c}\text { Number of } \\
\text { areolae rows } \\
\text { in } 10 \mu \mathrm{m}\end{array}$ & $\begin{array}{c}\text { Number of } \\
\text { areolae } \\
\text { in } 10 \mu \mathrm{m}\end{array}$ & \multicolumn{1}{|c|}{ Waterbody } \\
\hline $6.7-26.7$ & $7.1-21.1$ & $0.33-2.48$ & $6-11$ & $4-12$ & $\begin{array}{l}\text { Cheboksar Reservoir } \\
\text { (separation valves) }\end{array}$ \\
\hline $6.7-24.4$ & $10.0-21.1$ & $0.41-3.14$ & $6-10$ & $5-11$ & $\begin{array}{l}\text { Cheboksar Reservoir } \\
\text { (valves in the colony) }\end{array}$ \\
\hline $6.8-25.0$ & $12.8-25.7$ & $0.56-2.94$ & $8-12$ & $6-12$ & Ivankovo Reservoir \\
\hline $14.4-37.1$ & $10.0-18.9$ & $0.30-0.92$ & $6-8$ & $5-10$ & $\begin{array}{l}\text { Sestroretsk Razliv } \\
\text { Reservoir }\end{array}$ \\
\hline
\end{tabular}

\section{The variability of morphological features of Aulacoseira granulata and $A$. muzzanensis according to published data}

Table 2

\begin{tabular}{|c|c|c|c|c|l|}
\hline $\begin{array}{c}\text { Valve } \\
\text { diameter, } \\
\mu \mathrm{m}\end{array}$ & $\begin{array}{c}\text { Valve } \\
\text { height, } \mu \mathrm{m}\end{array}$ & $\begin{array}{c}\text { Mantle height to } \\
\text { valve diameter } \\
\text { ratio }\end{array}$ & $\begin{array}{c}\text { Number of } \\
\text { areolae rows } \\
\text { in } 10 \mu \mathrm{m}\end{array}$ & $\begin{array}{c}\text { Number of } \\
\text { areolae in } 10 \\
\mu \mathrm{m}\end{array}$ & \multicolumn{1}{|c|}{ References } \\
\hline \multicolumn{7}{|c|}{} & \multicolumn{5}{|c|}{\begin{tabular}{c} 
Aulacoseira granulata \\
\hline $5-21$
\end{tabular}} & $8-15$ & $8-12$ & $\begin{array}{l}\text { Zabelina } \text { et al., 1951 } \\
\text { (as Melosira granulata })\end{array}$ \\
\hline $5-21$ & $5-22$ & & $8-15$ & $6-14$ & $\begin{array}{l}\text { Skabichevsky, 1960 } \\
\text { (as Melosira granulata })\end{array}$ \\
\hline $2-21$ & & & $8-15$ & $8-12$ & $\begin{array}{l}\text { Davydova, Moiseeva, } \\
\text { 1992 }\end{array}$ \\
\hline $4-30$ & $5-24$ & $>0.8$ & $7-15$ & $5-12$ & $\begin{array}{l}\text { Krammer, Lange- } \\
\text { Bertalot, 1991 }\end{array}$ \\
\hline $3.5-19.5$ & $11-20$ & & $8-12$ & $9-16$ & Genkal, 1992 \\
\hline $10-21$ & $12.8-24$ & & $7-8$ & $6-8$ & Genkal, Yeshko, 1998 \\
\hline $3-30$ & $4-24$ & & $7-15$ & & Houk, 2003 \\
\hline $7-20$ & $7.7-13.3$ & & $10-14$ & $7-14$ & $\begin{array}{l}\text { Genkal, Mikheyeva, } \\
2006\end{array}$ \\
\hline $3.6-27.7$ & $12-16.8$ & $0.3-5.4^{*}$ & $8-20$ & $8-15$ & Genkal, Trifonova, 2006 \\
\hline $4.3-18.8$ & $10.0-26.6$ & & $9-15$ & $8-18$ & Maystrova et al., 2007 \\
\hline $10.0-24.4$ & $13-21$ & $0.4-3.2^{*}$ & $9-12$ & $10-12$ & $\begin{array}{l}\text { Genkal, Golokolenova, } \\
2008\end{array}$ \\
\hline $3.9-20.7$ & $3.6-21.6$ & $0.2-4.3^{*}$ & $8-15$ & $9-16$ & $\begin{array}{l}\text { Genkal, Gorokhova, } \\
2008\end{array}$ \\
\hline $6.4-12.1$ & $13.3-17.9$ & & $8-16$ & $5-14$ & $\begin{array}{l}\text { Genkal, Kulikovskiy, } \\
2008\end{array}$ \\
\hline $2.7-27.0$ & $7.8-24$ & $0.5-5.3^{*}$ & $6-15$ & $5-14$ & Genkal, Trifonova, 2008 \\
\hline $6.6-14.4$ & $16.6-23.5$ & & $8-10$ & $8-10$ & $\begin{array}{l}\text { Popovskaya, Genkal, } \\
2008\end{array}$ \\
\hline
\end{tabular}


Table 2 (continued)

\begin{tabular}{|c|c|c|c|c|c|}
\hline $3.0-11.5$ & $10-17$ & & $10-15$ & & Manoylov et al., 2009 \\
\hline $5.7-22.8$ & $20.0-26.6$ & $0.8-3.7^{*}$ & $6-12$ & $7-12$ & $\begin{array}{l}\text { Genkal, Okhapkin, } \\
2010\end{array}$ \\
\hline $7.8-14.3$ & $10.7-21.0$ & & $7-9$ & $7-10$ & $\begin{array}{l}\text { Genkal, Bondarenko, } \\
2011\end{array}$ \\
\hline $7.8-14.3$ & $10.7-21.0$ & & $7-9$ & $7-10$ & Genkal et al., 2011a \\
\hline $7.1-17$ & $9.3-22.8$ & & $7-11$ & $7-14$ & Genkal, Trifonova, 2011 \\
\hline $5.5-17.7$ & $12-18$ & & $8-12$ & $9-14$ & Popovskaya et al., 2011 \\
\hline $7.8-20.0$ & $20-24.4$ & & $7-8$ & & Genkal et al., 2011b \\
\hline $5-23.3$ & $10-21$ & & 10 & $6-12$ & Genkal, Romanov, 2012 \\
\hline $3-30$ & $4-24$ & & $7-15$ & & Kiss et al., 2012 \\
\hline $6.2-8.4$ & $12.6-13.4$ & & $13-14$ & & Bazhenova et al., 2013 \\
\hline $5-20$ & $7.8-17.8$ & & $8-9$ & $7-11$ & $\begin{array}{l}\text { Genkal, Okhapkin, } \\
2013\end{array}$ \\
\hline $6.6-18.8$ & $13.3-20$ & & $8-12$ & $8-12$ & Genkal et al., 2013a \\
\hline $6.4-15.5$ & $14.3-22.8$ & & $8-11$ & $9-14$ & Genkal et al., 2013b \\
\hline $14.3-23.3$ & $10-17$ & & $7-8$ & 7 & Genkal, Afonina, 2014 \\
\hline $7.1-7.8$ & $17.8-25.5$ & & $8-10$ & $8-10$ & Genkal, Lepskaya, 2013 \\
\hline $4.3-6.0$ & $11.3-16$ & & $7-9$ & & Ector et al., 2015 \\
\hline $5-17$ & $14.4-20$ & & $9-12$ & $8-12$ & $\begin{array}{l}\text { Genkal, Okhapkin, } \\
2016\end{array}$ \\
\hline $4.3-27.8$ & $11.7-25.5$ & & $6-10$ & $5-12$ & Genkal et al., 2015 \\
\hline $8.3-16.7$ & $13.3-18.9$ & & $8-9$ & 9 & Genkal, Bilous, 2015 \\
\hline $6.0-8.9$ & $10-15.5$ & & $9-13$ & $8-10$ & $\begin{array}{l}\text { Genkal, Yarmoshenko, } \\
2013\end{array}$ \\
\hline $2-30$ & $5-24$ & & $8-15$ & $9-14$ & Kulikovskiy et al., 2016 \\
\hline $5.7-20.0$ & $12-19.1$ & & $7-13$ & $6-14$ & $\begin{array}{l}\text { Chudaev, Gololobova, } \\
2016\end{array}$ \\
\hline \multicolumn{6}{|c|}{ Aulacoseira muzzanensis } \\
\hline $12-14$ & $6-8$ & & $11-13$ & & Meister, 1912 \\
\hline $12-25$ & $4-8$ & & 12 & 20 & $\begin{array}{l}\text { Zabelina et al., 1951(as } \\
\text { Melosira granulata var. } \\
\text { muzzanensis) }\end{array}$ \\
\hline $8-25$ & $4-8$ & $0.3-0.6$ & \begin{tabular}{|l} 
separation \\
valves $13-15 ;$ \\
thin struc- \\
ture valves \\
in the colony \\
$11-13$, coarse \\
structured \\
valves $7-10$
\end{tabular} & \begin{tabular}{|l} 
separation \\
valves $12-13$ \\
and $17-21 ;$ \\
thin struc- \\
ture valves \\
in the colony \\
20, coarse \\
structured \\
valves $8-10$
\end{tabular} & $\begin{array}{l}\text { Krammer, Lange- } \\
\text { Bertalot, } 1991\end{array}$ \\
\hline
\end{tabular}




\begin{tabular}{|c|c|c|c|c|}
\hline & & $\begin{array}{l}\text { separation } \\
\text { valves } 13-15 ; \\
\text { thin struc- } \\
\text { ture valves } \\
\text { in the colony } \\
11-13, \text { coarse } \\
\text { structured } \\
\text { valves } 7-10\end{array}$ & $\begin{array}{l}\text { separation } \\
\text { valves } 12-13 \\
\text { and } 17-21 ; \\
\text { thin struc- } \\
\text { ture valves } \\
\text { in the col- } \\
\text { ony } 16-20, \\
\text { coarse struc- } \\
\text { tured valves } \\
8-10\end{array}$ & Krammer, 1991 \\
\hline $9-24$ & $5-13$ & $7-15$ & & $\begin{array}{l}\text { Potapova, English, } \\
2011\end{array}$ \\
\hline
\end{tabular}

Note. ${ }^{*}$ - based on measurements on negatives from the archive of S. I. Genkal.

A certain relationship was observed in all A. granulata populations (Fig. 1a, 2a) with increasing valve diameter, the mantle height to valve diameter ratio decreases and the $\mathrm{h} / \mathrm{d}$ ratio typical for A. muzzanensis (0.3-0.8), is found in large-diameter valves (Fig. 1a, 2a). Such correlation occurs in other representatives of the genus Aulacoseira (Fig. 2b, 3a, b). Skabichevsky (1960) also noted that $A$. granulata narrow cells have longer valves and its cells with a larger diameter are shorter.
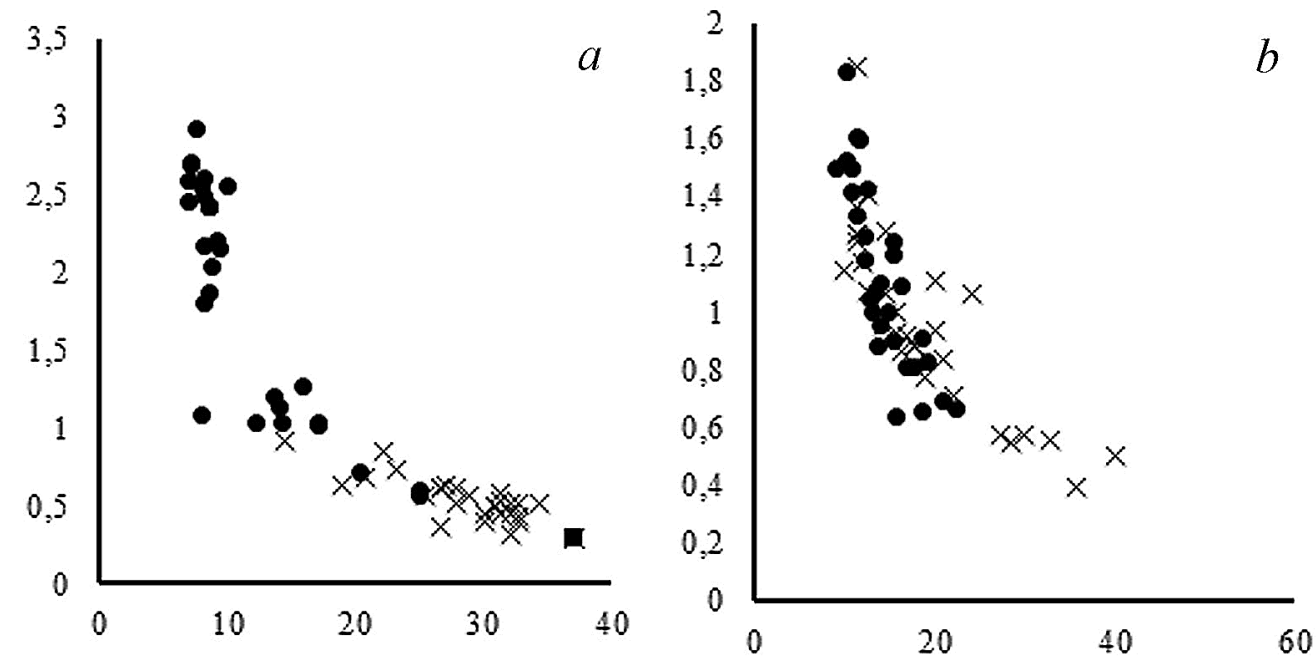

Fig. 2. (a) Aulacoseira granulata, relationship between valve diameter (axis $\mathrm{X}, \mu \mathrm{m}$ ) and mantle height to valve diameter ratio (axis Y), •: Ivankovo reservoir, $\times$ : Sestroretsky Razliv reservoir. (b) A. islandica, relationship between valve diameter (axis $\mathrm{X}, \mu \mathrm{m}$ ) and mantle height to valve diameter ratio (axis Y), •: Amur River, $\times$ : Khanka Lake.

According to the diagnosis of Krammer and Lange-Bertalot (1991) A. muzzanensis is characterized by shorter valves, a lower $\mathrm{h} / \mathrm{d}$ ratio and a larger number of areolae in $10 \mu \mathrm{m}$ than $A$. granulata (Table 2). According to the published data the first two 
characteristics correspond with A. granulata (Table 2), but the valve diameter and the height of its mantle significantly vary in a manner that may be due to seasonal, longterm or interpopulational variability (Genkal, 1990, 2007; Kiss et al., 2013; Genkal, Chekryzheva, 2016). In A. granulata the ratio of the mantle height to valve diameter is more than 0.8, and in A. muzzanensis it is 0.3-0.6 (Table 2). Measurement and calculation of this characteristic in the other populations of $A$. granulata has shown similar results (Table 1). Measurements from published micrographs (Florin, 1970: Fig. 21-23) show that the mantle height to valve diameter ratio in A. granulata varies from 0.19 to 0.24. Krammer, Lange-Bertalot (1991: Taf. 20, Fig. 1) present a micrograph of A. muzzanensis with a ratio of mantle height to valve diameter of about 0.8 . Noteworthy that measurements of A. muzzanensis from micrographs (Krammer, 1991: Fig. 3, 4, 6, 8, 10, 10a, 11, 11a, 12, 13, 16) have shown that in this species population from the type locality the $\mathrm{h} / \mathrm{d}$ ratio varies quite a bit - from 0.3 to 1.06 - and this ratio depends on the valve diameter as in other representatives of the genus (Fig. 1a, 2, 3).
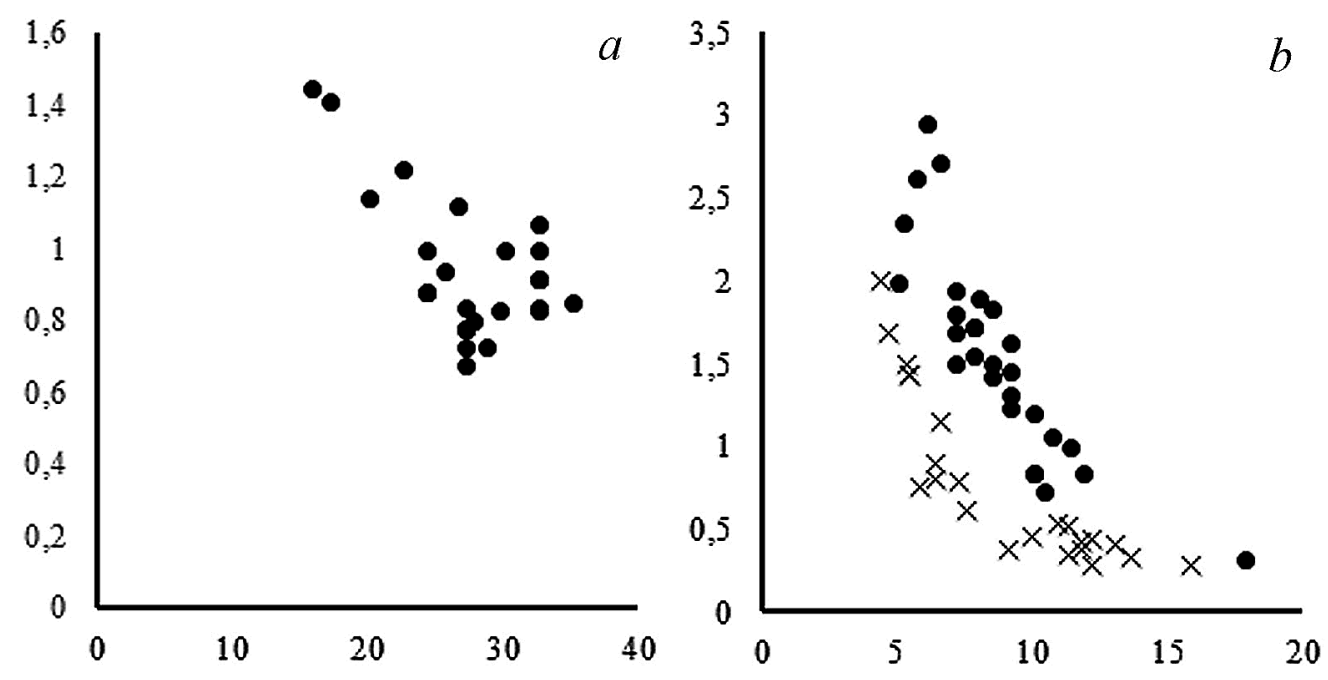

Fig. 3. (a) Aulacoseira baicalensis, relationship between valve diameter (axis X, $\mu \mathrm{m}$ ) and mantle height to valve diameter ratio (axis Y), •: Middle Baikal, $\times$ : Krasnoe Lake. (b) A. subarctica, relationship between valve diameter (axis $\mathrm{X}, \mu \mathrm{m})$ and mantle height to valve diameter ratio (axis Y), •: Kurilskoe Lake, ×: Krasnoe Lake.

In A. muzzanensis separation valves and those in filaments can have the same number areolae in $10 \mu \mathrm{m}$ as in $A$. granulata, as well as much more (16-21) (Table 2). However, according to the literature, such numbers of areolae were found in $A$. granulata too: Genkal (1992) and Genkal and Gorokhova (2008) reported 16 and Maystrova et al. (2007) reported 18. In illustrations of A. granulata (Florin, 1970: Fig. 21-23) the number of areolae in $10 \mu \mathrm{m}$ ranges from14 to 20. Measurements from micrographs indicate that the number of areolae in $10 \mu \mathrm{m}$ on separation valves of $A$. muzzanensis 
can differ even on one valve of the colony (14 and 18: Krammer, 1991: Fig. 11a), which indicates a wider range of variability of this characteristic coinciding with that of A. muzzanensis. Skabichevskiy (1960) also noted variations in the number of rows and areolae on the valve mantle and attributed it to cell age - old frustules have 11.2 rows of pores in $10 \mu \mathrm{m}$ and 6.7 pores in a row and young ones have 13.2 rows and 13.3 pores.

In our opinion the results of our investigations and data from the literature confirm the correctness of referring Melosira granulata var. muzzanensis to the synonym of Aulacoseira granulata and make it possible to refine the diagnosis of the latter.

Aulacoseira granulata (Ehrenb.) Simonsen, 1979, Bacillaria, 2: 58, emend. Genkal (Plate I)

$\equiv$ Gallionella granulata Ehrenb., 1843, Abh. Königl. Akad. Wiss. Berlin, 1841: 415. $\equiv$ Melosira granulata (Ehrenb.) Ralfs in Pritchard, 1861, A History of Infusoria, including the Desmidiaceae and Diatomaceae, British and Foreign, $4^{\text {th }}$ ed.: 820.

= M. granulata var. angustissima (Ehrenb.) O. F. Müll., 1899, Hedwigia, 38(6): 315, pl. 12, fig. 28.

= M. muzzanensis F. Meist., 1912, Beitr. Kryptogamenfl. Schweiz 4(1): 41, 232, pl. 1, fig. 10. $\equiv$ M. granulata var. muzzanensis (F. Meist.) Hust., 1930, Die Süßwasser-Flora Mitteleuropas, Heft 10: 88, fig. 7. $\equiv$ Aulacoseira muzzanensis (F. Meist.) Krammer, 1991, Nova Hedwigia, 52(1-2): 98.

= A. granulata var. australiensis (Grunow) Moro, 1991, Arq. Biol. Technol. 34(2): 355 .

Frustule from low to high, cylindrical with several bands. Valves straight or bent along central axis, round, flat, 2.0-37.1 $\mu \mathrm{m}$ in diameter. Valve face areolae arranged randomly, sometimes only along margin, or are structureless. Mantle with longitudinal straight or inclined areola rows 6-20, and transverse undulate rows (4-20 in $10 \mu \mathrm{m}$ ). Circular groove shallow, narrow, ringleist not wide. Linking spins along margin small, bifurcated, teardrop-shaped, branching, elongated and pointed; separation valves with long coarse spines of different lengths (1-7), overlying similarly shaped structureless parts (grooves) of adjacent valve mantle. Auxospores spherical.

Aulacoseira granulata var. australiensis has a range of variability of quantitative features (valve diameter 18-31 $\mu \mathrm{m}$, height $11-17 \mu \mathrm{m}, 8-16$ striae in $10 \mu \mathrm{m}, 8-16$ areolae in $10 \mu \mathrm{m}$ ) coinciding with those of $A$. granulata var. granulata (Table 2). According to the diagnosis, areolae on the valve face of $A$. granulata var. australiensis are located over the entire surface; however, they are absent in the type variety in the author's opinion (Moro, 1991). This statement is untrue, and areolae in A. granulata var. granulata are distributed over the entire surface (Krammer, Lange-Bertalot, 1991: Taf. 17, Fig. 7-10; Houk, 2003: Tab. XXV, Fig. 14, 15). One of the features that differentiates A. granulata var. australiensis from the type species is a smaller number of spines in the latter (2-3) compared to A. granulata var. australiensis (3-4). However, according to our data, their number may vary from 1 to 7 (Fig. 1b). In our opinion, in view of the above, A. granulata var. australiensis belongs to the group $A$. granulata var. granulata. 

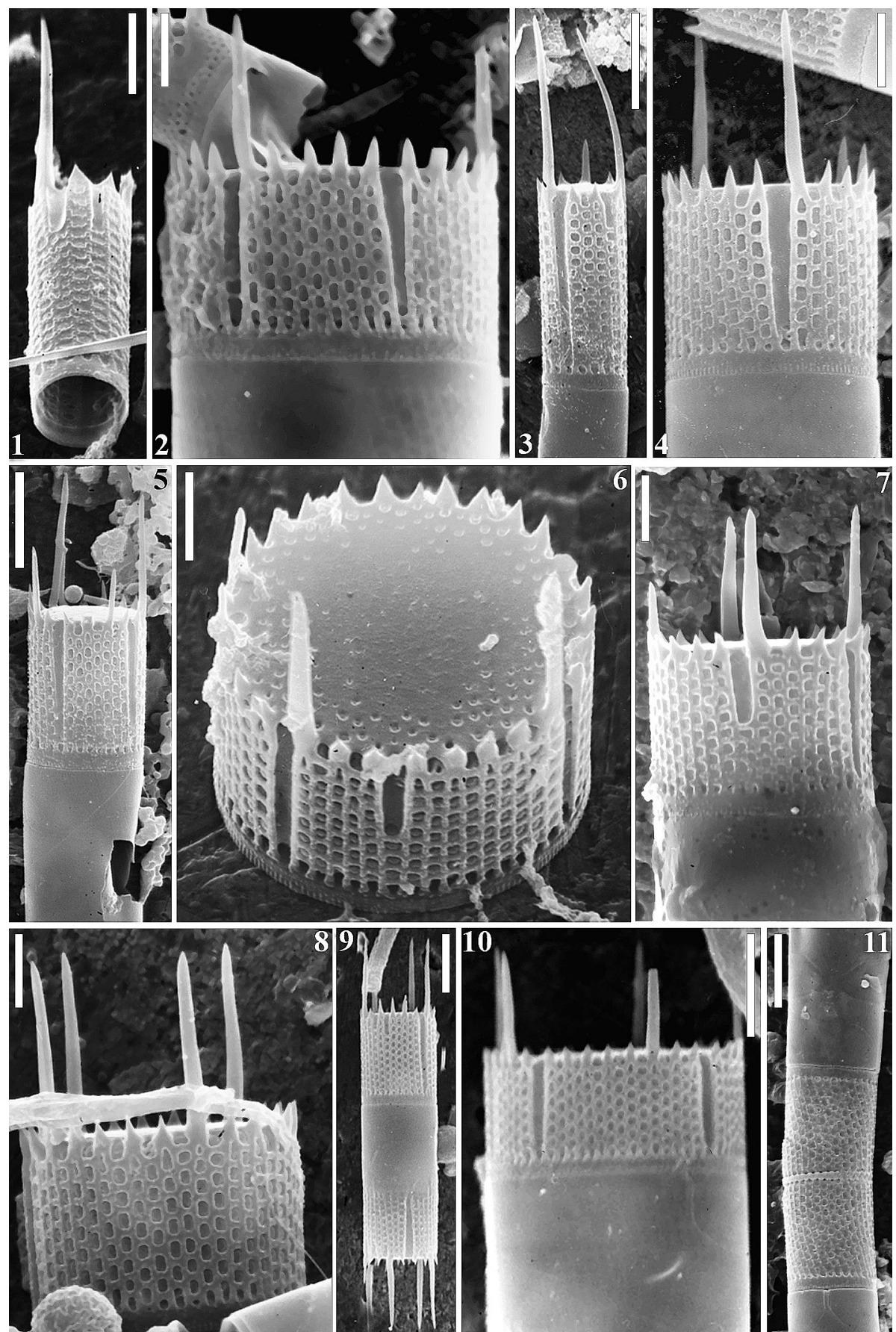

Plate I. Aulacoseira granulata, SEM (Ivan'kovo Reservoir, 16 VII 1981, sample 817, IBIW).

1-10 - external view, the separation valves, variations in the number of spines and their length; $11-$ valves in the colony. Scale bars: $1,2,4,6-8-5 \mu \mathrm{m} ; 6,8,12-14-10 \mu \mathrm{m}$. 


\section{Acknowledgments}

This study was conducted in the framework of state task projects "Systematics, Diversity and Phylogeny of Aquatic Autotrophic Organisms in Russia and Other Regions of the World" (No. AAAA-A18-118012690095-4) and "Evolution of environment and climate under the influence of natural and anthropogenous factors" (№ 0154-2018-0004).

\section{References}

Algae of Ukraine: Diversity, Nomenclature, Taxonomy, Ecology and Geography. Vol. 2. Bacillariophyta. 2009. Ruggell: 413 p.

Balonov I. M. 1975. Preparation of algae for electron microscopy. Metodika izucheniya boigeotsenozov [Methods for the study of biocenoses]. Moscow: 87-89. (In Russ.).

Bazhenova O. P., Genkal S. I., Shakhoval V. E., Bragina E. A. 2013. Centric diatom algae (Centrophyceae) of the Bukhtarma reservoir (the Irtysh River, Kazakhstan). Algologia 23(3): 308-317. (In Russ.). https://doi.org/10.15407/alg23.03.308

Chudaev D. A., Gololobova M. A. 2016. Diatomovye vodorosli ozera Glubokogo (Moskovskaya oblast) [Diatom algae in Glubokoe Lake (Moscow Region)]. Moscow: 447 p. (In Russ.).

Bethge H. 1925. Melosira und ihre Planktonbegleiter. Pflanzenforschung 3: 1-82.

Davydova N. N., Moiseeva A. I. 1992. Genera: Aulacosira Thw. Diatomovye vodorosli SSSR (iskopaemye $i$ sovremennye) [The diatoms of the USSR (fossil and recent)].Vol. II. Fasc. 2. St. Petersburg: 76-85. (In Russ.).

Ermolaeva L. M. 1967. Phytobenthos in Ponds of Bolsherechensk District. Proceedings of Omsk Medical Institute 77: 42-46. (In Russ.).

Florin M.-B. 1970. The fine structure of some pelagic fresh water diatom species under the scanning electron microscope. I. Svensk Botanisk Tidskrift 64: 51-64.

Genkal S. I. 1990. Morphology of centric diatoms: aspects of seasonal variability in the frustules. Flora i produktivnost pelagicheskikh $i$ litiralnykh phitotsenozov vodoemov basseina Volgi [Flora and productivity of pelagic and littoral phytocoenoses of the Volga basin reservoir]. Leningrad: 237-253. (In Russ.).

Genkal S. I. 1992. Atlas diatomovukh vodorosley planktona reki Volgi [Atlas of the diatom algae of the plankton in the Volga River]. St. Petersburg: 128 p. (In Russ.).

Genkal S. I. 2007. Morphology, taxonomy, ecology and distribution of small-sized species of the genus Stephanodiscus (Bacillariophyta). 2. Stephanodiscus makarovae. Botanicheskii zhurnal 92(2): 241-248. (In Russ.).

Genkal S. I., Afonina E. A. 2014. Additions to the flora of centric diatom algae of the Velikaya River (Pskov Region). Botanicheskii Zhurnal 99(11): 1238-1242. (In Russ.). https://doi.org/10.1134/S1234567814110032

Genkal S. I., Bilous O. P. 2015. Centric diatoms (Cenrophyceae) of the Lower Portion of the Southern Bug River (Ukraine). International Journal on Algae 17(4): 339-350. https://doi.org/10.1615/InterJAlgae.v17.i4.20

Genkal S. I., Bondarenko N. A. 2011. Diatom algae in mountain lakes of the Dzherginskiy Reserve (the Baikal area). 1. Centrophyceae. Povolzhskiy Ecologicheskiy Zhurnal 2: 127-136. (In Russ.).

Genkal S. I., Bondarenko N. A., Shur L. A. 2011a. Diatomovye vodorosli ozer yuga i severa Vostochnoy Sibiri [Diatoms of lakes from south and north parts of Eastern Siberia]. Rybinsk: 72 p. (In Russ.).

Genkal S. I., Chekryzheva T. A. 2016. On morphology, taxonomy, ecology and distribution of Cyclotella rossii Håkansson (Bacillariophyta). Nova Hedwigia 102(3-4): 399-421.

https://doi.org/10.1127/nova_hedwigia/2015/0316 
Genkal S. I., Chekryzheva T. A., Komulaynen S. F. 2015. Diatomovye vodorosli planktona Ladozhskogo ozera i vodoemov ego basseyna [Diatom algae in waterbodies and watercourses of Karelia]. Moscow: 202 p. (In Russ.).

Genkal S. I., Golokolenova T. B. 2008. Centric diatom algae of the Tsimlyansk reservoir. Povolzhskiy Ecologicheskiy Zhurnal 3: 178-189. (In Russ.).

Genkal S. I., Gorokhova O. G. 2008. Materials to the Flora of Diatom Algae (Centrophyceae) in Waterbodies of Samarskaya Luka. Proceedings of Samara Scientific Center of the Russian Academy of Sciences 10(5/1): 206-216. (In Russ.).

Genkal S. I., Kulikovskiy M. S. 2008. Centrophyceae (Bacillariophyta) from Polistovo-Lovatsky sohagnous tract (Rdeisky State Nature Reserve). Botanicheskii zhurnal 93(5): 1200-1209. (In Russ.).

Genkal S. I., Kulikovskiy M. S., Kuznetsova I. V. 2013a. New data to Centrophyceae (Bacillariophyta) of Lake Baikal, Russia. Algologia 23(1): 3-9. (In Russ.). https://doi.org/10.15407/alg23.01.003

Genkal S. I., Kulikovskiy M. S., Mikheeva T. M., Kuznetsova I. V., Luk'yanova E. V. 2013b. Diatomovye vodorosli planktona reki Svisloch i ee vodokhranilishch [Diatoms in plankton of the Svisloch River and its reservoirs]. Moscow: 236 p. (In Russ.).

Genkal S. I., Lepskaya E. V. 2013. Materials to the flora of centric diatom algae in Lake Nerpichye (the Kamchatka River Estuary). Investigations of Aquatic Biological Resources of Kamchatka and the Northwest Pacific Ocean 31: 62-73. (In Russ.).

Genkal S. I., Mikheyeva T. M. 2006. Materials on the flora of diatom algae (Centrophyceae, Bacillariophyta) of the Neman River and its tributaries. Botanicheskii zhurnal 91(3): 420-424. (In Russ.).

Genkal S. I., Motylkova I. V., Konovalova N. V. 2011b. New data on the flora of diatom algae (Centrophyceae) in waterbodies of Sakhalin Island. Inland Water Biology 4: 408-418. https://doi.org/10.1134/S1995082911030084

Genkal S. I., Okhapkin A. G. 2010. Diatoms (Centrophyceae) in the Kama reservoir phytoplankton. Povolzhskiy Ecologicheskiy Zhurnal 3: 254-262. (In Russ.).

Genkal S. I., Okhapkin A. G. 2013. Centric Diatoms (Centrophyceae) in the lower reaches of the Oka River (Russian Federation). Hydrobiological Journal 49(3): 41-57. https://doi.org/10.1615/HydrobJ.v49.i3.40

Genkal S. I., Okhapkin A. G. 2016. Plankton Centrophyceae (Bacillariophyta) of the Klyaz'ma River (Russian Federation). Hydrobiological Journal 52(2): 35-48. https://doi.org/10.1615/HydrobJ.v52.i2.40

Genkal S. I., Romanov R. E. 2012. Centric diatom (Centrophyceae, Bacillariophyta) in watercourses and Boilies of water in Southeast of West Siberian Plain and Polar Ural. Contemporary Problems of Ecology 5(4): 399-412. https://doi.org/10.1134/S199542551204004X

Genkal S. I., Trifonova I. S. 2006. Materials on the flora of Bacillariophyta of the Narva river and Narva reservoir (North-Western Russia). 1. Centrophyceae. Botanicheskii zhurnal 91(5): 693-697. (In Russ.).

Genkal S. I., Trifonova I. S. 2008. Electron-microscopy study of centric diatoms in phytoplankton of the Lake Krasnoe. Mnogoletnie izmeneniya biologicheskikh soobshchesto mezotrofnogo ozera v usloviyakh klimaticheskikh fluktuatsii $i$ evtrofirovaniya [Long-term changes of biological communities in mezotrophic lake in conditions of climatic fluctuations and eutrophication]. St. Petersburg: 35-41. (In Russ.).

Genkal S. I., Trifonova I. S. 2011. Centric diatoms (Centrophyceae, Bacillariophyta) in plankton of the Neva Bay of the Gulf of Finland. Algologia 21(1): 106-110. (In Russ.).

Genkal S. I., Yarmoshenko L. P. 2013. Centric diatoms (Bacillariophyta) of the cooling pond of the Khmelnitskiy nuclear power station (Ukraine). Hydrobiological Journal 49(1): 51-63. https://doi.org/10.1615/HydrobJ.v49.i1.60

Genkal S. I., Yeshko T. A. 1998. Materials to flora of Bacillariophyta of the water bodies of Karelia (Russia). Konchezero Lake I. Centrophyceae. Algologia 8(1): 11-13. (In Russ.). 
Houk V. 2003. Atlas of Freshwater Centric Diatoms with a Brief Key and Descriptions. Part I. Melosiraceae, Orthoseiraceae, Paraliaceae and Aulacoseiraceae. Czech Phycology Supplement, Volume 1. Olomouc: 27 p.

Hustedt F. 1930. Bacillariophyta (Diatomeae) Zweite Auflage. Die Süsswasser-Flora Mitteleuropas. Heft 10. Jena: 466 p.

Kiss K. T., Genkal S. I., Ector L., Molnar L., Duleba M., Biro P. 2013. Morphology, taxonomy and distribution of Stephanodiscus triporus (Bacillariophyceae) and related taxa. European Journal of Phycology 48(4): 363-379. https://doi.org/10.1080/09670262.2013.843204

Kiss K. T., Klee R., Ector L., Ács É. 2012. Centric diatoms of large rivers and tributaries in Hungary: morphology and biogeographic distribution. Acta Botanica Croatica 71(2): 311-363. https://doi.org/10.2478/v10184-011-0067-0

Krammer K. 1991. Morphology and taxonomy in some taxa of the genus Aulacoseira Thwaites (Bacillariophyceae) II. Taxa in the A. granulata-, italica- and lirata-groups. Nova Hedwigia 53: 477-496.

Krammer K., Lange-Bertalot H. 1991. Bacillariophyceae 3. Teil: Centrales, Fragilariaceae, Eunotiaceae. Sußwasserflora von Mitteleuropa. Bd 2/3. Stuttgart, Jena: 576 S.

Kulikovskiy M. S., Glushchenko A. M., Genkal S. I., Kuznetsova I. V. 2016. Opredelitel diatomovykh vodorosley Rossii [Identification book of Diatoms from Russia]. Yaroslavl: 804 c. (In Russ.).

Kuzmin G. V., Elizarova V. A. 1967. Phytoplankton in the Sheksna Reach of The Rybinsk Reservoir in 1963-1965. Proceedings of the Institute for Biology of Inland Waters 15: 104-133. (In Russ.).

Manoylov K. M., Ognjanova-Rumenova N., Stevenson R. J. 2009. Morphotype variations in subfossil diatom species of Aulacoseira in 24 Michigan Lakes, USA. Acta Botanica Croatica 68(2): 401-419.

Maystrova N. V., Genkal S. I., Scherbak V. I., Semenyak N. Ye. 2007. Centrophyceae in the upper section of the Kanev water reservour (Ukraine). Algologia 17(4): 467-475. (In Russ.).

Meister F. 1912. Die Kieselalgen der Schweiz. Beitr. zur Kryptogamenflora der Schweiz 4/1. Bern: $1-254$.

Moro R. S. 1991. Morphology of Aulacoseira granulata (Ehrenberg) var. australiensis (Grunow) nov. comb. unser light microscopy. Arquivos de Biologia e Tecnologia 34(2): 353-359.

Olszynski R. M., Zelazna-Wieczorek J. 2018. Aulacoseira pseudomuzzanensis sp. nov. and other centric diatoms from post iron ore mining reservoirs in Poland. Diatom Research 33(2): 155-185. https://doi.org/10.1080/0269249X.2018.1509886

Popovskaya G. I., Genkal S. I. 2008. Materials to the flora of diatom algae (Centrophyceae) from lakes of the Baikal Region and Transbaikalia. Inland Waters Biology 1: 311-319. (In Russ.). https://doi.org/10.1134/S1995082908040019

Popovskaya G. I., Genkal S. I., Likhoshway Ye. V. 2015. Diatoms of the plankton of Lake Baikal: Atlas and Key. Second Edition, Revised and Expanded. Novosibirsk: 180 p.

Potapova M., English J. 2011. Aulacoseira muzzanensis. Diatoms of North America. The source for diatom identification and ecology. https://diatoms.org/species/aulacoseira_muzzanensis (Date of access: 20 IX 2019).

Skabichevsky A. P. 1960. Planktonnye diatomovye vodorosli presnykh vod SSSR. Sistematika, ekologiya i rasprostranenie [Planktonic diatom algae of the USSR freshwaters. Systematics, ecology and distribution]. Moscow: 350 p. (In Russ.).

Tremarin P. I., Veiga Ludwig. T. A., Torgan, L. C. 2012. Ultrastructure of Aulacoseira brasiliensis sp. nov. (Coscinodiscophyceae) and comparison with related species. Fottea 12(2): 171-188. https://doi.org/10.5507/fot.2012.013

Wetzel C. E., Ector L., Bicudo D. C. 2014. Type analysis of Aulacoseira gessneri (Hustedt) Simonsen (Bacillariophyceae) from South America. Nova Hedwigia, Beiheft 143: 381-390. 
Zabelina M. M., Kiselev I. A., Proshkina-Lavrenko A. I., Sheshukova V. S. 1951. Opredelitel presnovodnyh vodoroslej SSSR. Vypusk 4. Diatomovye vodorosli. [Key to the freshwater algae of the U.S.S.R. Diatoms]. Moscow: 619 p. (In Russ.).

\section{Литература}

Algae of Ukraine: Diversity, Nomenclature, Taxonomy, Ecology and Geography. Vol. 2. Bacillariophyta. 2009. Ruggell: 413 p.

[Balonov] Балонов И.М. 1975. Подготовка водорослей к электронной микроскопии. Методика изучения биогеоценозов внутренних водоемов. М.: 87-89.

[Bazhenova et al.] Баженова О. П., Генкал С. И., Шаховал В. Е., Брагина Е. А. 2013. Центрические диатомовые водоросли (Centrophyceae) Бухтаринского водохранилища (р.Иртыш, Казахстан). Альгология 23(3): 308-317. https://doi.org/10.15407/alg23.03.308

Bethge H. 1925. Melosira und ihre Planktonbegleiter. Pflanzenforschung 3: 1-82.

[Chudaev, Gololobova] Чудаев Д. А., Гололобова М. А. 2016. Диатомовые водоросли озера Глубокого (Московская область). М.: 447 с.

[Davydova, Moiseeva] Давыдова Н. Н., Моисеева А. И. 1992. Роды: Aulacosira Thw. Диатомовые водоросли СССР (ископаемые и современные). T. II. Вып. 2. СПб.: 76-85.

[Ermolaeva] Ермолаева Л.М. 1967. Фитобентос прудов Большереченского района. Вопросы гигиены: труды Омского медицинского института 77: 42-46.

Florin M.-B. 1970. The fine structure of some pelagic fresh water diatom species under the scanning electron microscope. I. Svensk Botanisk Tidskrift. 64: 51-64.

[Genkal] Генкал С. И. 1990. Морфология панциря центрических диатомей: аспекты сезонной изменчивости. Флора и продуктивность пелагических и литоральных фитоценозов водоемов бассейна Волги. Л.: 237-253.

[Genkal] Генкал С. И. 1992. Атлас диатомовых водорослей планктона реки Волги. СПб.: 128 с.

[Genkal] Генкал С. И. 2007. Морфология, таксономия, экология и распространение мелкоразмерных видов Stephanodiscus (Bacillariophyta). 2. Stephanodiscus makarovae. Ботанический журнал 92(2): 241-248.

[Genkal, Afonina] Генкал С. И., Афонина Е. А. 2014. Дополнение к флоре центрических диатомовых водорослей (Centrophyceae) реки Великая (Псковская область). Ботанический журнал 99(11): 1238-1242. https://doi.org/10.1134/S1234567814110032

Genkal S. I., Bilous O. P. 2015. Centric diatoms (Cenrophyceae) of the Lower Portion of the Southern Bug River (Ukraine). International Journal on Algae 17(4): 339-350. https://doi.org/10.1615/InterJAlgae.v17.i4.20

[Genkal, Bondarenko] Генкал С. И., Бондаренко Н. А. 2011. Диатомовые водоросли горных озер Дзержинского заповедника (Прибайкалье) 1. Centrophyceаe. Поволжский экологический журнал 2: 127-136.

[Genkal et al.] Генкал С. И., Бондаренко Н. А., Щур Л. А. 2011а. Диатомовые водоросли озер юга и севера Восточной Сибири. Рыбинск: 72 с.

Genkal S. I., Chekryzheva T. A. 2016. On morphology, taxonomy, ecology and distribution of Cyclotella rossii Håkansson (Bacillariophyta). Nova Hedwigia 102(3-4): 399-421. https://doi.org/10.1127/nova_hedwigia/2015/0316

[Genkal et al.] Генкал С. И., Чекрыжева Т. А., Комулайнен С. Ф. 2015. Диатомовые водоросли водоемов и водотоков Карелии. М.: 202 с.

[Genkal, Golokolenova] Генкал С. И., Голоколенова Т. Б. 2008. Центрические диатомовые водоросли Цимлянского водохранилища. Поволжский экологический журнал 3: 178-189.

[Genkal, Gorokhova] Генкал С. И., Горохова О. Г. 2008. Материалы к флоре диатомовых водорослей (Centrophyceae) в водоемах Самарской Луки. Известия Самарского научного иентра Российской академии наук 10(5/1): 206-216. 
[Genkal, Kulikovskyi] Генкал С. И., Куликовский М. С. 2008. Центрические диатомовые (Bacillariophyta) Полистово-Ловатского сфагнового массива (Государственный природный заповедник «Рдейский»). Ботанический журнал 93(8): 1200-1209.

[Genkal et al.] Генкал С. И., Куликовский М. С., Кузнецова И. В. 2013а. Материалы к флоре Centrophyceae (Bacillariophyta) озера Байкал (Россия). Альгология 23(1): 3-9. https://doi.org/10.15407/alg23.01.003

[Genkal et al.] Генкал С. И., Куликовский М. С., Михеева Т. М., Кузнецова И. В., Лукьянова Е. В. 2013b. Диатомовые водоросли планктона реки Свислочь и ее водохранилищ. М.: 236 с.

[Genkal, Lepskaya] Генкал С. И., Лепская Е. В. 2013. Материалы к флоре центрических диатомовых водорослей оз. Нерпичье (эстуарий р.Камчатка). Исследования водных биологических ресурсов Камчатки и северо-западной части Тихого океана 31: 62-73.

[Genkal, Mikheyeva] Генкал С. И., Михеева Т. М. 2006. Материалы к флоре диатомовых водорослей (Centrophyceae, Bacillariophyta) реки Неман и ее притоков. Ботанический журнал 91(3): 420-424.

Genkal S. I., Motylkova I. V., Konovalova N. V. 2011b. New data on the flora of diatom algae (Centrophyceae) in waterbodies of Sakhalin Island. Inland Water Biology 4: 408-418. https://doi.org/10.1134/S1995082911030084

[Genkal, Okhapkin] Генкал С. И., Охапкин А. Г. 2010. Диатомовые водоросли (Centrophyceae) в фитопланктоне Камских водохранилищ. Поволжский экологический журнал 3: 254-262.

Genkal S. I., Okhapkin A. G. 2013. Centric Diatoms (Centrophyceae) in the lower reaches of the Oka River (Russian Federation). Hydrobiological Journal 49(3): 41-57. https://doi.org/10.1615/HydrobJ.v49.i3.40

Genkal S. I., Okhapkin A. G. 2016. Plankton Centrophyceae (Bacillariophyta) of the Klyaz'ma River (Russian Federation). Hydrobiological Journal 52(2): 35-48. https://doi.org/10.1615/HydrobJ.v52.i2.40

Genkal S. I., Romanov R. E. 2012. Centric diatom (Centrophyceae, Bacillariophyta) in watercourses and Boilies of water in Southeast of West Siberian Plain and Polar Ural. Contemporary Problems of Ecology 5(4): 399-412. https://doi.org/10.1134/S199542551204004X

[Genkal, Trifonova] Генкал С. И., Трифонова И. С. 2006. Материалы к флоре Bacillariophyta реки Нарва и Нарвского водохранилища (Северо-Запад России). 1. Centrophyceae. Ботанический журнал 91(5): 693-697.

[Genkal, Trifonova] Генкал С. И., Трифонова И. С. 2008. Электронно-микроскопическое исследование центрических диатомей планктона оз. Красного. Многолетние изменения биологических сообществ мезотрофного озера в условиях климатических флуктуаций и эвтрофирования. СПб.: 35-41.

[Genkal, Trifonova] Генкал С. И., Трифонова И. С. 2011. Центрические диатомовые водоросли (Centrophyceae, Bacillariophyta) планктона Невской губы Финского залива. Альгология 21(1): 106-110.

Genkal S. I., Yarmoshenko L. P. 2013. Centric diatoms (Bacillariophyta) of the cooling pond of the Khmelnitskiy nuclear power station (Ukraine). Hydrobiological Journal 49(1): 51-63. https://doi.org/10.1615/HydrobJ.v49.i1.60

[Genkal, Yeshko] Генкал С. И., Иешко Т. А. 1998. Материалы к флоре Bacillariophyta водоемов Карелии. Кончезеро. I. Centrophyceаe. Альгология 8(1): 11-13.

Houk V. 2003. Atlas of Freshwater Centric Diatoms with a Brief Key and Descriptions. Part I. Melosiraceae, Orthoseiraceae, Paraliaceae and Aulacoseiraceae. Czech Phycology Supplement, Volume 1. Olomouc: 27 p.

Hustedt F. 1930. Bacillariophyta (Diatomeae) Zweite Auflage. Die Süsswasser-Flora Mitteleuropas. Heft 10. Jena: 466 p. 
Kiss K. T., Genkal S. I., Ector L., Molnar L., Duleba M., Biro P. 2013. Morphology, taxonomy and distribution of Stephanodiscus triporus (Bacillariophyceae) and related taxa. European Journal of Phycology 48(4): 363-379. https://doi.org/10.1080/09670262.2013.843204

Kiss K. T., Klee R., Ector L., Ács É. 2012. Centric diatoms of large rivers and tributaries in Hungary: morphology and biogeographic distribution. Acta Botanica Croatica 71(2): 311-363. https://doi.org/10.2478/v10184-011-0067-0

Krammer K. 1991. Morphology and taxonomy in some taxa of the genus Aulacoseira Thwaites (Bacillariophyceae) II. Taxa in the A. granulata-, italica- and lirata-groups. Nova Hedwigia 53: 477-496.

Krammer K., Lange-Bertalot H. 1991. Bacillariophyceae 3. Teil: Centrales, Fragilariaceae, Eunotiaceae. Sußwasserflora von Mitteleuropa. Bd 2/3. Stuttgart, Jena: 576 S.

[Kulikovskiy et al.] Куликовский М. С., Глущенко А. М., Генкал С. И., Кузнецова И. В. 2016. Определитель диатомовых водорослей России. Ярославль: 804 с.

[Kuzmin, Elizarova] Кузьмин Г. В., Елизарова В. А.1967. Фитопланктон Шекснинского плеса Рыбинского водохранилища в 1963-1965 гг. Труды института биологии внутренних вод 15 : 104-133.

Manoylov K. M., Ognjanova-Rumenova N., Stevenson R. J. 2009. Morphotype variations in subfossil diatom species of Aulacoseira in 24 Michigan Lakes, USA. Acta Botanica Croatica 68(2): 401-419.

[Maystrova et al.] Майстрова Н. В., Генкал С. И., Щербак В. И., Семенюк Н. Е. 2007. Centrophyсеае верхней части Каневского водохранилища (Украина). Альгология 17(4): 467-475.

Meister F. 1912. Die Kieselalgen der Schweiz. Beitr. zur Kryptogamenflora der Schweiz 4/1. Bern: $1-254$.

Moro R. S. 1991. Morphology of Aulacoseira granulata (Ehrenberg) var. australiensis (Grunow) nov. comb. unser light microscopy. Arquivos de Biologia e Tecnologia 34(2): 353-359.

Olszynski R. M., Zelazna-Wieczorek J. 2018. Aulacoseira pseudomuzzanensis sp. nov. and other centric diatoms from post iron ore mining reservoirs in Poland. Diatom Research 33(2): 155-185. https://doi.org/10.1080/0269249X.2018.1509886

[Popovskaya, Genkal] Поповская Г. И., Генкал С. И. 2008. Материалы к флоре диатомовых водорослей (Centrophyceae) озер Прибайкалья и Забайкалья. Биология внутренних вод 1: 311-319. https://doi.org/10.1134/S1995082908040019

Popovskaya G. I., Genkal S. I., Likhoshway Ye. V. 2015. Diatoms of the plankton of Lake Baikal: Atlas and Key. Second Edition, Revised and Expanded. Novosibirsk: 180 p.

Potapova M., English J. 2011. Aulacoseira muzzanensis. Diatoms of North America. The source for diatom identification and ecology. https://diatoms.org/species/aulacoseira_muzzanensis (Дата обращения: 20 IX 2019).

[Skabichevsky] Скабичевский А. П 1960. Планктонные диатомовые водоросли пресных вод СССР. Систематика, экология и распространение. Москва: 350 с.

Tremarin P. I., Veiga Ludwig. T. A., Torgan, L. C. 2012. Ultrastructure of Aulacoseira brasiliensis sp. nov. (Coscinodiscophyceae) and comparison with related species. Fottea 12(2): 171-188. https://doi.org/10.5507/fot.2012.013

Wetzel C. E., Ector L., Bicudo D. C. 2014. Type analysis of Aulacoseira gessneri (Hustedt) Simonsen (Bacillariophyceae) from South America. Nova Hedwigia, Beiheft 143: 381-390.

[Zabelina et al.] Забелина М. М., Киселев И. А., Прошкина-Лавренко А. И., Шешукова В. С. 1951. Определитель пресноводных водорослей СССР. Выпуск 4. Диатомовые водоросли. М.: 619 c. 